\title{
NOTE ON THE CLAUSILIUM OF A CHINESE SPECIES OF CLAUSILIA.
}

\author{
By Professor H. A. Pilsbry. \\ Read 10th April, 1908.
}

In the course of some studies on Chinese Clausiliæ I had occasion to examine the structure of $C$. Bocki described by our fellow-member Mr. E. R. Sykes in these Proceedings. ${ }^{1}$ This species is reckoned by its author to be a member of the section Pseudonenia. It agrees fully with that group in characters of the shell and in the general shape of the clausilium; but there is, on the outer face of the latter, at its lower third, a stout acute hook, arising near the palatal side, and directed transversely to the length of the plate, as shown in Figs. $a$ and $b$. No such structure has been observed in any other Pseudonenia, or in fact in any other Clausilia known to me. The only comparable

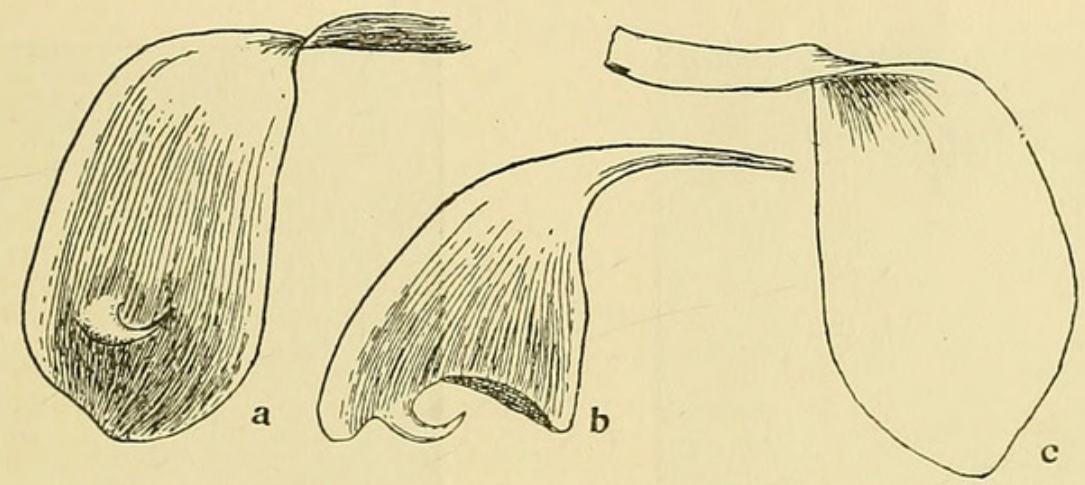

Clausilium of Clansilia Bocki, Sykes. $a$, external view; $b$, view from above ; $c$, inside.

structure, so far as I know, is found in the section Parazaptyx, Pils., ${ }^{2}$ in which there is a transverse plate or buttress across the outside of the clausilium. Parazaptyx is a Loochooan form, not at all nearly related to C. Bocki. It belongs to another line of specialization.

In the case of Parazaptyx I had thought the function of the transverse buttress might be to strengthen the clausilium; but obviously no such idea can be entertained regarding the hook of C. Bocki. The hook on this clausilium reminds one of those inwardly projecting hooks in the apertures of some Polygyras, which seem adapted to catch and hold intending intruders rather than to exclude them.

1 Proc. Malac. Soc., vol. i, p. 263 (1895).

2 Proc. Acad. Nat. Sci. Philad., 1904, p. 834, pl. lvii, figs. 101, 104. 

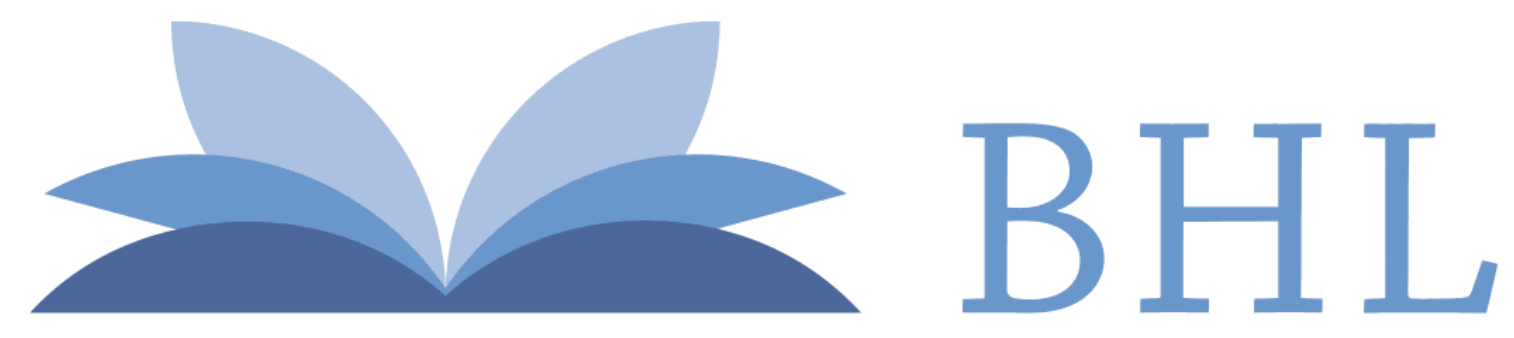

\section{Biodiversity Heritage Library}

Pilsbry, Henry Augustus. 1908. "NOTE ON THE CLAUSILIUM OF A CHINESE SPECIES OF CLAUSILIA." Proceedings of the Malacological Society of London 8, 119-119.

View This Item Online: https://www.biodiversitylibrary.org/item/100060

Permalink: https://www.biodiversitylibrary.org/partpdf/202980

\section{Holding Institution}

Field Museum of Natural History Library

\section{Sponsored by}

Smithsonian

\section{Copyright \& Reuse}

Copyright Status: Public domain. The BHL considers that this work is no longer under copyright protection.

This document was created from content at the Biodiversity Heritage Library, the world's largest open access digital library for biodiversity literature and archives. Visit BHL at https://www.biodiversitylibrary.org. 